\title{
Improvements on Pozzolanic Reactivity of Coal Refuse by Thermal Activation
}

\author{
Yuan Yao $^{1} \&$ Henghu Sun ${ }^{2}$ \\ ${ }^{1}$ Pacific Resources Research Center, Pharmaceutical and Chemical Science Program, PRCC, University of the \\ Pacific, USA \\ ${ }^{2}$ Pacific Resources Research Center, School of Engineering and Computer Science, PRRC, University of the \\ Pacific, USA \\ Correspondence: Henghu Sun, Pacific Resources Research Center, School of Engineering and Computer Science, \\ PRRC, University of the Pacific, 3601 Pacific Ave, Stockton, CA 95211, USA. Tel: 1-209-946-2767. \\ Email:hsun@pacific.edu
}

Received: January 12, 2012 Accepted: January 18, 2012 Online Published: June 4, 2012

doi:10.5539/ep.v1n2p33 URL: http://dx.doi.org/10.5539/ep.v1n2p33

This research is funded by US Department of Energy: DE-EE0003496

\begin{abstract}
Today, coal refuse as industrial solid waste stockpiled on the ground is one of the greatest threats to the environment. One of the practical solutions to utilize this huge amount of solid waste is to activate the coal refuse and utilize it as substitution for portion of ordinary Portland cement. The key purpose of activation is to enhance the pozzolanic property of the coal refuse.Many scientists and engineers found that thermal activation is a practical approach on increasing pozzolanic property. For thermal activation, temperature and time are two important parameters which significantly determine the activation effect. In this paper, a systematic research has been conducted to seek for anoptimal solution for enhancing pozzolanic reactivity of the relatively inert solid waste-coal refuse in order to improve the utilization efficiency and economy benefit forconstruction and building materials. The mechanical property analysis shows that coal refusethat activated at $700^{\circ} \mathrm{C}$ to $800^{\circ} \mathrm{C}$ with 1 hour to 1.5 hours has much higher reactivity when compared with coal refuse activated at $500^{\circ} \mathrm{C}$ to $600{ }^{\circ} \mathrm{C}$ with 1 hour to 1.5 hours. And 28-dayscompressive strength value of prepared blended cementitious material containing $25 \%$ of the $700^{\circ} \mathrm{C} 1 \mathrm{~h}$ activated coal refuse based pozzolanareaches $43.4 \mathrm{MPa}$, which is higher than 28 -days strength of OPC group as control.
\end{abstract}

Keywords: coal refuse, thermal activation, cementitious material, pozzolanic property

\section{Introduction}

Today, coal is still considered as the primary fuel for electricity generation (CTAB, 2010). However, the coal mining industry also generates a huge amount of inert solid waste during the mining process. And coal refuse is one of the largest forms of waste from the coal mining industry and is generally defined as a low BTU-value material under the parameters of minimum ash content combined with maximum heating value (US EPA, 2008). It is estimated that coal mines in the US generate 109 million metric tons (120 million short tons) of coal refuse from 600 coal preparation plants in 21 coal-producing states annually. In China, the accumulative stockpile of coal refuse has reached 3.8 billion metric tons and it is estimated that over 200 million metric tons of this waste is impounded annually. Therefore, at present, such large quantities of the solid waste have not only occupied a great amount of land but also caused many serious environmental problems and how to ecologically recycle the inert solid waste has become a very challenging topic and attracts the attention from the scientists and policy makers.

However, coal refuse is relative inert solid wastes due to their major mineralogical compositions as stable aluminosilicate minerals at the ambient conditions, such as quartz, feldspar etc., which is hard toutilize as cementitious material for its lack of pozzolanic properties. Previous studieshave been conducted on the cementitious material composed of thermal activated coal refuse as pozzolanic material. N. Zhang et al. have successfully recycled red mud and coal refuse into cementitious material by thermal activation at $600^{\circ} \mathrm{C}$ (Zhang et al., 2011a, 2011b), and J. Zhang has demonstrated that coal refuse contains good pozzolanic properties after thermal activation(Zhang et al., 2010a, 2010b, 2010c). Other scientists tried to use integrated thermal and 
chemical activation to increase the pozzolanic properties of the coal refuse (Yu et al., 2006; Li et al., 2006; Yi et al., 2009; Chen et al., 2006). In this paper, a systematic study isconducted on evaluating the pozzolanic property of a coal refuse based cementitious material, which contains $25 \%$ coal refuse based pozzolana in cementitious material by activated at different temperature and time duration.

\section{Material and Methods}

\subsection{Raw Material}

The raw material used in this experiment includes coal refuse and US type I/II cement. The coal refuse was generated by a mining operation situated within the Central Appalachian Coal Basin in southwest Virginia, eastern Kentucky and southern West Virginia. The coal seams located near these operation sites were deposited during the Pennsylvania period and are located in the Pottsville Group from Pocahontas through the lower portions of the Allegheny formation. The chemical analysis was performed using an X-ray fluorescence (XRF-1700) analyzer, and mineral composition was detected by X-ray diffraction (XRD) with the Rigaku Ultimate.

\subsection{Activation Procedure}

Raw coal refuse is rock like irregular particles, therefore, it is necessary to crush and mill raw coal refuse into fine power coal refuse for cementitious material utilization. Coal refuse was crushed and then followed by grounding in a laboratory ball mill (50kg capacity) for $45 \mathrm{~min}$. Then the milled coal refuse was put inside of the furnace (Lindberg Blue M, Thermo Scientific) forthermal activationat different condition. The activation temperature $\left(600^{\circ} \mathrm{C}-800^{\circ} \mathrm{C}\right)$ and time $(0.5 \mathrm{~h}-1.5 \mathrm{~h})$ were controlled as two significant parameters during the whole process to evaluate the pozzolanic property of the activated coal refuse. After the thermal activation process, the resultingsamples were removed from the furnace and allowed to cool spontaneously to room temperature in air. They were crushed in the laboratory ball mill to the Blaine's specific surface area of $601 \mathrm{~m}^{2} / \mathrm{kg}$.

\subsection{Mortar Test}

The compositions of different groups tested are listed in Table 1. It was important to use the same standard mixing method for the high-performance mortar tests, and all mortar samples were mixed according to ASTM C305 (Standard Practice for Mechanical Mixing of Hydraulic Cement Pastes and Mortars of Plastic Consistency) and ASTM C109 (Standard Test Method for Compressive Strength of Hydraulic Cement Mortars) (ASTM C305, 2008; ASTM C109, 2008). The procedures were performed as described in the standard: all of the mixing water was placed into the bowl; cement was added to the water and the mixer was started at a low speed $(140 \pm 5 \mathrm{r} / \mathrm{min})$ for 30 seconds; aggregate was then added over a 30 -second period while mixing at a low speed; and mixing was then increased to a medium speed $(285 \pm 10 \mathrm{r} / \mathrm{min})$ for 30 seconds of mixing. The mixer was stopped for 90 seconds to scrape down all of the mortar paste followed by mixing for 90 seconds at medium speed. Finally, the mixer was stopped, and mortar was cast into the mold. Cubic specimens $(50 \mathrm{~mm} \times 50 \mathrm{~mm} \times 50 \mathrm{~mm})$ were cast for each mixture for the unconfined compressive strength test (ASTM C109, 2008). Compression tests were performed on various specimens at seven curing ages $(3,7,28$ Days). The test cubes were cured in a moist cabinet at $95 \%$ humidity and $23^{\circ} \mathrm{C}$.

Table 1. Chemical, physical and mineral analysis of raw material

\begin{tabular}{lll}
\hline & Coal refuse & Cement \\
\hline $\mathrm{Al}_{2} \mathrm{O}_{3}(\%)$ & 13.89 & 2.78 \\
$\mathrm{SiO}_{2}(\%)$ & 47.43 & 13.99 \\
$\mathrm{CaO}(\%)$ & 4.55 & 62.11 \\
$\mathrm{Fe}_{2} \mathrm{O}_{3}(\%)$ & 11.19 & 3.34 \\
$\mathrm{SO}_{3}(\%)$ & 0.27 & 2.54 \\
$\mathrm{~K}_{2} \mathrm{O}(\%)$ & 3.24 & 0.29 \\
$\mathrm{MnO}_{2}(\%)$ & 0.16 & 0.13 \\
$\mathrm{TiO}_{2}(\%)$ & 1.02 & 0.10 \\
${\mathrm{Specific} \mathrm{gravity}\left(\mathrm{t} / \mathrm{m}^{3}\right)}_{\mathrm{Specific} \mathrm{surface}\left(\mathrm{m}^{2} / \mathrm{kg}\right)}$ & 2.70 & 3.11 \\
Loss of ignite $(\%)$ & 601 & 445 \\
Major mineral component & 9.88 & 2.67 \\
& Quartz & LarniteHatruriteBrow \\
& Chloride & nmillerite \\
\hline
\end{tabular}




\subsection{XRD and SEM Results}

The target samples were prepared for observation using an XL30 FEG scanning electron microscope (SEM) with energy-dispersive X-ray microanalyses.

\section{Experimental Results and Discussion}

\subsection{Pozzolanic Properties of Coal Refuse}

In this test, the compressive strength test was used to evaluate the pozzolanic properties of the coal refuse based on cementitious material. As in Table 2, according to recipe of coal refuse based cementitious material (CR), the coal refuse activated at different condition and were mixed respectively to form different cementitious material groups. And the compressive strength results are presented in Figures 1, 2 and 3. From Figure 1, it is clearly seen that the 3 day strength of all coal refuse based cementitious material reaches more than $27 \mathrm{MPa}$. The 3 days strength of samples activated at $700^{\circ} \mathrm{C}$ and $800^{\circ} \mathrm{C}$ is higher than $28 \mathrm{MPa}$ which is slightly better than that of ordinary Portland cement (OPC) group. When compared with the groups activated at different temperature, it is found that the groups with $1 \mathrm{~h}$ and $1.5 \mathrm{~h}$ activation show better pozzolanic property than the group with $0.5 \mathrm{~h}$ activation. As for the 7 and 28 day strength performance, it is also found the similar patternwhich shows that the 7 day strength of group activated at $700^{\circ} \mathrm{C}$ for $1 \mathrm{~h}$ reaches to $36.8 \mathrm{MPa}$, and it is higher than other groups in the 7 day strength test. In the 28 Day strength test, the strength of groups with $700^{\circ} \mathrm{C} 1 \mathrm{~h}$ activation and $800^{\circ} \mathrm{C} 1 \mathrm{~h}$ activation reaches $43.4 \mathrm{MPa}$ and $43.1 \mathrm{MPa}$ respectively, which is higher than the $40 \mathrm{MPa}$ strength of OPC at 28 days. From these three sets of strengthtests at different curing age, it can be concluded that the activation temperature from $700^{\circ} \mathrm{C}$ to $800^{\circ} \mathrm{C}$ usually shows better activation performance than the activation at $500^{\circ} \mathrm{C}$ to $600^{\circ} \mathrm{C}$ when the process was conducted at the same time duration. And as for the same temperature activation condition, $1 \mathrm{~h}$ and $1.5 \mathrm{~h}$ activation shows better effect than activation within $0.5 \mathrm{~h}$. However, when the economy and energy input consideration was input for an optimal solution, it can be referred that the activation at $700^{\circ} \mathrm{C}$ within $1 \mathrm{~h}$ should be the practical answer.

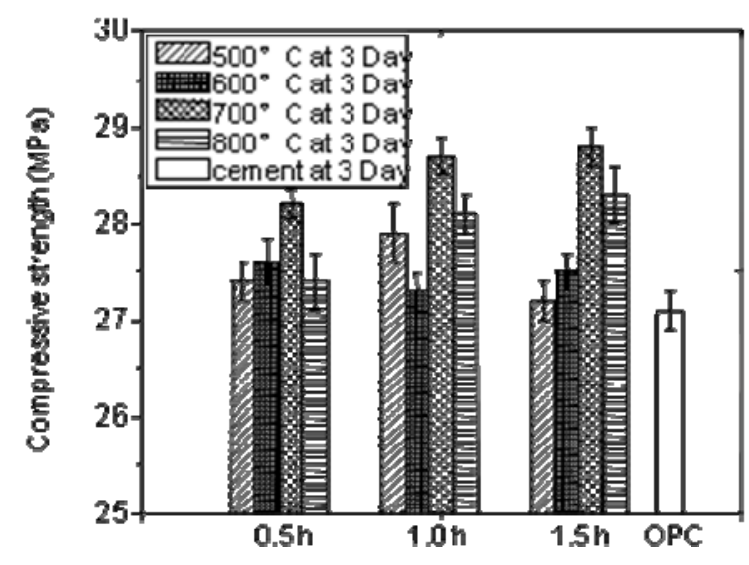

Figure 1. Compressive strength test at 3 Day

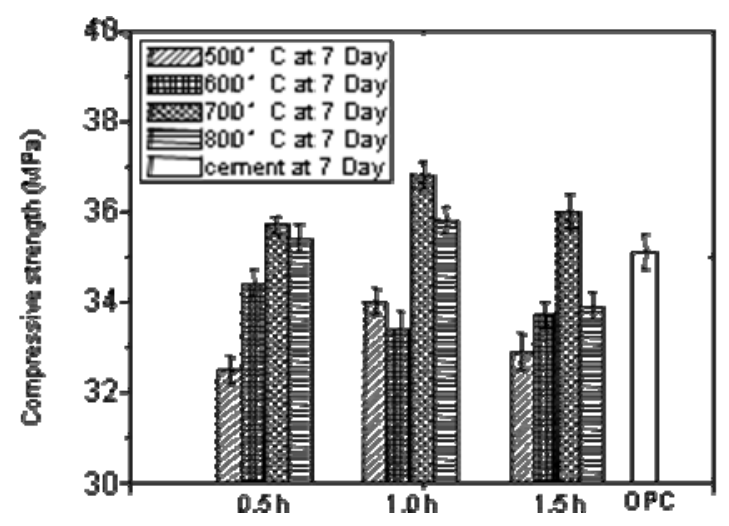

Figure 2. Compressive strength test at 7 Day 


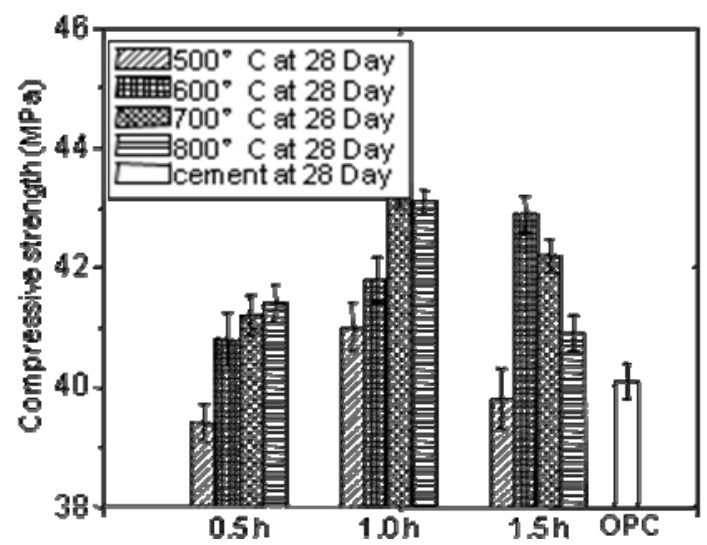

Figure 3. Compressive strength test at 28 Day

Table 2. Compositions of different tested groups

\begin{tabular}{lllllll}
\hline Sample & $\begin{array}{l}\text { Cementitious materials (C) } \\
\mathrm{kg} / \mathrm{m}^{3}\end{array}$ & $\begin{array}{l}\text { Sand (S) } \\
\mathrm{kg} / \mathrm{m}^{3}\end{array}$ & Water(W) $\mathrm{kg} / \mathrm{m}^{3}$ & $\mathrm{~W} / \mathrm{C}$ & $\mathrm{S} / \mathrm{C}$ \\
\cline { 2 - 5 } & Cement & Pozzolana & & & & \\
\hline OPC & 500 & 0 & 1375 & 242 & 0.485 & 2.75 \\
$\mathrm{CR}$ & 375 & 125 & 1375 & 242 & 0.485 & 2.75 \\
\hline
\end{tabular}

Pozzolana $=$ Coal refuse + Gypsum (Coal refuse: Gypsum=20:1)

\subsection{SEM Analysis}

SEM was conducted on four $1 \mathrm{~h}$ activated samples (from $500^{\circ} \mathrm{C}$ to $800^{\circ} \mathrm{C}$ ), the SEM images in Figures 4 to 7 illustrates the morphological characteristics of thermal-activated coal refuse. As shown from Figures 4 and 5, the coal refuse activated from $500^{\circ} \mathrm{C}$ to $600^{\circ} \mathrm{C}$ within $1 \mathrm{~h}$ shows the "scale-shaped" layered structure; however, as shown in Figures 6 and 7, this structure was destroyed when the temperature reached higher than $600^{\circ} \mathrm{C}$. This might be due to the decomposition of minerals such as chlorite, muscovite, and kaolinite, which caused todestroy the layered structure. It is reported that kaolinite and muscovite disappeared at $600^{\circ} \mathrm{C}$ to $800^{\circ} \mathrm{C}$ (Zhang et al., 2011; Zhang et al., 2010). The kaolinite begins to decrease because of their transformation into metakaolin at $600^{\circ} \mathrm{C}$ to $800^{\circ} \mathrm{C}$. And some previous study shows that the muscovite amorphizes at high temperature and high pressure (Zanazzi et al., 2002). Mazzucato et al has indicates that muscovite $2 \mathrm{M}_{1}$ shows a major phase transition in coal refuse at about $800^{\circ} \mathrm{C}$ and the reaction taking in $700^{\circ} \mathrm{C}$ to $1000^{\circ} \mathrm{C}$ is truly a dehydroxylation process, involving the muscovite $2 \mathrm{M}_{1}$ gradually dehydroxylated to muscovite HT (Mazzucato et al., 1999). The generated amorphous materialsfrom parts of inert aluminosilicate minerals might be contribute to the improved pozzolanic properties. And this finds well agrees with morphological changes on thermal activation of coal waste (Zhang et al., 2011; Zhang et al., 2010).

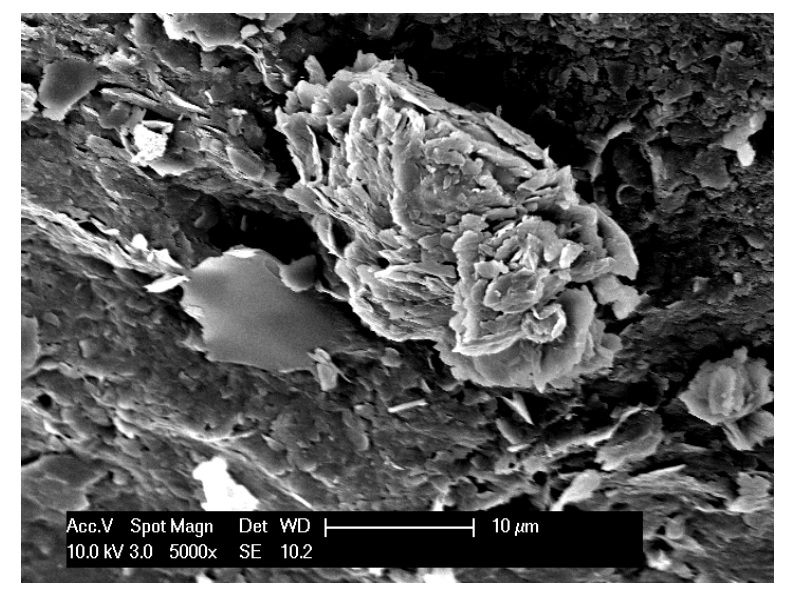

Figure 4. SEM of coal refuse activated at $500^{\circ} \mathrm{C}$ for 1 hour 


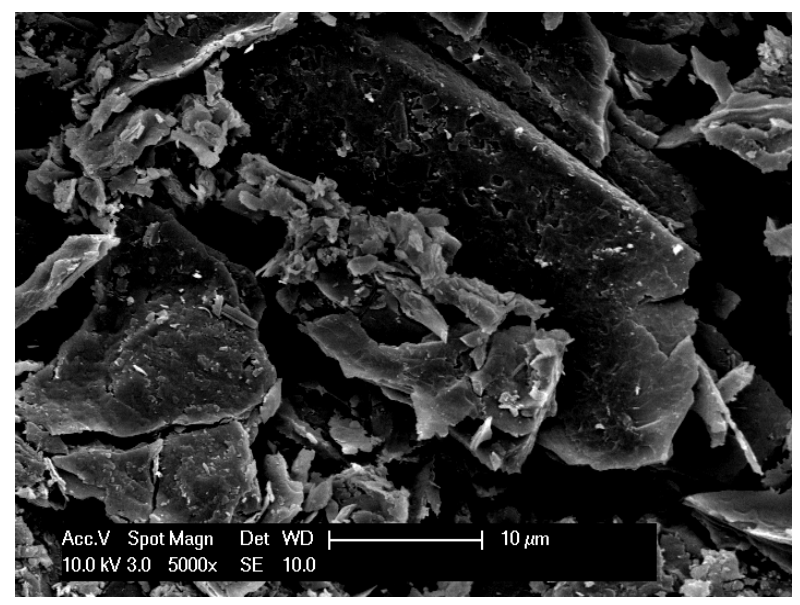

Figure 5. SEM of coal refuse activated at $600^{\circ} \mathrm{C}$ for 1 hour

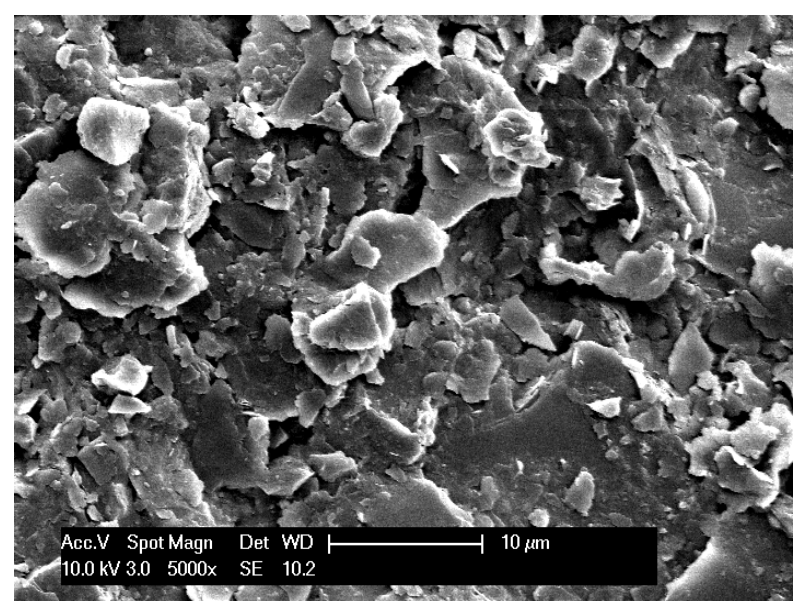

Figure 6. SEM of coal refuse activated at $700^{\circ} \mathrm{C}$ for 1 hour

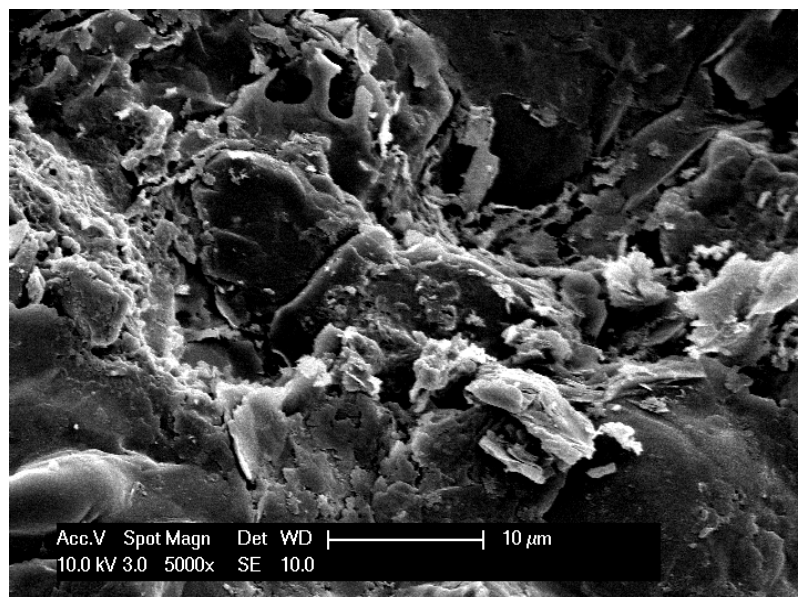

Figure 7. SEM of coal refuse activated at $800^{\circ} \mathrm{C}$ for 1 hour

\section{Conclusion}

Coal refuse shows different pozzolanic properties when they were activated at different time and temperature. When the pozzolanic properties were investigated from $500^{\circ} \mathrm{C}$ to $800^{\circ} \mathrm{C}$, it is found that coal refuse activated at $700^{\circ} \mathrm{C}$ to $800^{\circ} \mathrm{C}$ shows better pozzolanic property than that activated at $500^{\circ} \mathrm{C}$ to $600^{\circ} \mathrm{C}$. And 1 hour activation shows better performance than the $0.5 \mathrm{~h}$ activation. Through the SEM image analysis, it is found that the coal refuse has layered scale microstructure at $500^{\circ} \mathrm{C}$ to $600^{\circ} \mathrm{C}$, while this structure was destroyed when the 
temperature rise up to $700^{\circ} \mathrm{C}$ to $800^{\circ} \mathrm{C}$. And this perhaps caused by the mineral phase change during the thermal activation.

\section{References}

ASTM C109. (2008). Standard test method for compressive strength of hydraulic cement mortar (Using 2-in. or [50-mm) cube specimens). Annual Book of ASTM Standards, 4.01, American Society for Testing and Materials, Conshohocken, PA.

ASTM C305. (2008).Standard practice for mechanical mixing of hydraulic cement pastes and mortars of plastic consistency. Annual Book of ASTM Standards, 4.01, American Society for Testing and Materials, Conshohocken, PA.

Chen, H. X. (2006). Study on the formation mechanism of cementitious properties of aluminosilicate materials-coal gangue. Post-Doctor Thesis, Tsinghua University, Beijing.

CTAB. (2010). International energy agency coal industry advisory board- 32nd plenary meeting discussion report. OECD Headquarters in Paris.

Li, D. X. et al. (2006). Research on cementitious behavior and mechanism of pozzolanic cement with coal $\begin{array}{lllll}\text { gangue. Cement } \quad \text { Concrete } & \text { Research, }\end{array}$ http://dx.doi.org/10.1016/j.cemconres.2004.11.004

Mazzucato, E., Artioli, G., \& Gualtieri, A. (1999). High temperature dehydroxylation of muscovite-2M1: A kinetic study by in situ XRPD. Physics and Chemistry of Minerals, 26(5), pp. 375-381. http://dx.doi.org/10.1007/s002690050197

US EPA. (2008). Materials characterization paper in support of the advanced notice of proposed rulemaking: Identification of nonhazardous materials that are solid waste-Coal refuse. Dec. 16.

Yi, Z. L. et al. (2009). Iron ore tailing used for the preparation of cementitious material by compound thermal activation. International Journal of Minerals Metallurgy and Materials, 16(3), 1-4. http://dx.doi.org/10.1016/S1674-4799(09)60064-9

Yu, Y.M. et al. (2009). Influences of mechanochemistry effect on coal gangue-cement properties. Bulletin of the Chinese Ceramic Society, 25(4), 59-61. http:// dx.doi.org/cnki:ISSN:1001-1625.0.2006-04-014

Zanazzi, P, \& Pavese, A. (2002). Behavior of micas at high pressure and high temperature. Reviews in Mineralogy and Geochemistry, 46(1), pp. 99-106. http://dx.doi.org/10.2138/rmg.2002.46.02

Zhang, J. X. et al. (2010a). Corrosion behavior of steel rebar in coal gangue based mortar. Journal of Zhejiang University Science A, 11(5), pp. 382-388. http://dx.doi.org/10.1631/jzus.A0900443

Zhang, J. X. et al. (2010b). Correlation between 29 Si polymerization and cementitious activity of coal gangue. Journal of Zhejiang University Science A, 10(9), 1334-1340. http:// dx.doi.org/10.1631/jzus.A0920237

Zhang, J. X. et al. (2010c). Study on Microstructure and Mechanical Property of Inter- facial Transition Zone between Limestone Aggregate and Sialite Paste. Construction and Building Materials, 23(11), 3393-3397. http://dx.doi.org/10.1016/j.conbuildmat.2009.06.037

Zhang, N., et al. (2011a). Evaluation of blends bauxite-calcination-method red mud with other industrial wastes as a cementitious material: Properties and hydration characteristics. Journal of Hazardous Material, 185(1), 329-335. http:// dx.doi.org/10.1016/j.jhazmat.2010.09.038.

Zhang, N. et al. (2011b). Pozzolanic behaviour of compound-activated red mud-coal gangue mixture. Cement and Concrete Research, 41(3), 270-278. http://dx.doi.org/10.1016/j.cemconres.2010.11.013. 